Dvoruk V.I., * Borak K.V.**

*National Aviation University, Kyiv city, Ukraine,

**Zhytomyr Agrarian and Technical College,

Zhytomyr city, Ukraine

E-mail: vidvoruk@gmail.com

\section{RESEARCH OF THE DEGREE OF FIXATION OF ABRASIVE PARTICLE IN THE SOIL}

An adaptation was developed for measuring the soil shear resistance.. Studied the influence of the type and moisture content of the soil, as well as on the content of the root system on it, on the degree of fixation of the abrasive particles in the soil. The regularities of the degree of fixation of the abrasive particles in the soil are established depending on the mentioned factors. The directions of further research are determined.

Key words: abrasive particle, soil, degree of anchorage of abrasive particles, soil cultivating machines, seeding machines, coefficient of internal friction, specific gravity.

\title{
Introduction
}

So far, the soil as an element of the tribosystem has not been studied sufficiently, therefore the properties of this abrasive environment, which determine the intensity of deterioration of the working elements of soil cultivating and sowing machines, are not fully elucidated.

The abrasive particles in the soil that interact with the surface of the working organ can be fixed on one, two or three sides, that is, to have a different number of degrees of freedom, which substantially affects the flow of processes in the contact area of the particle with the surface of the friction.

The characteristic of the bound state of particles is the degree of abrasion fixation [1], which is one of the leading factors in the wear process. For example, when using heavy disk blowers, the front row of disks vanishes $1,5 \ldots 2$ times faster than the rear, which is explained by the decrease in the degree of fastening of abrasive particles in the soil, which is processed in the back row, as other factors in both rows of discs are the same .

In order to take into account the degree of abrasion fixation in the design and production of working bodies of soil cultivating and sowing machines with high wear resistance, it is necessary to develop a method for determining this indicator and carry out its quantitative assessment. The study of the effect of soil moisture on the degree of abrasion fixation will allow you to choose the optimal timing for soil cultivation to reduce the intensity of deterioration of the working organs of soil cultivating and sowing machines.

\section{Analysis of published materials in this problem}

In the works [2, 3] the leading role of the strength of sand fixation in the soil mass on its abrasiveness is noted. For example, in a dry soil, where sand particles are firmly fixed, the most intense abrasive wear of the metal occurs [2].

Soil is an environment the particles in which are in a non-rigid state and are able to move relative to one another, and also to rotate around its own axis under the action of normal and tangential stresses from external action [4]. The degree of fixation of abrasive particles in the soil is characterized by tangential stress and is determined by the displacement tensile strength $\tau[5]$.

The degree of fixation of abrasive particles in the soil depends on the number of dust particles smaller than $0.01 \mathrm{~mm}[4]$.

At present, during the design and operation of the working bodies of soil tillage and sowing machines, the degree of fixing of abrasive particles is not taken into account, since its actual value for soils of Ukraine remains uncertain.

\section{Goal}

To study the impact of type and humidity of soil and the content of root system in it on the degree of fixation of abrasive particles in plowing soli layer.

\section{Methods of research}

The resistance of the soil shear consists of the adhesion due to the molecular and capillary forces, as well as the forces of internal friction [6]. 
For a real soil, the displacement resistance can be determined by the formula:

$$
\tau=c+\sigma \cdot f
$$

where $f$ is a coefficient of internal internal friction of the soil;

$\sigma$ is the normal tension, $\mathrm{Pa}$;

$c$ is the specific coupling, $\mathrm{Pa}$.

In the field conditions the soil shear resistance was determined on the developed device, the scheme of which is shown in Figure 1.

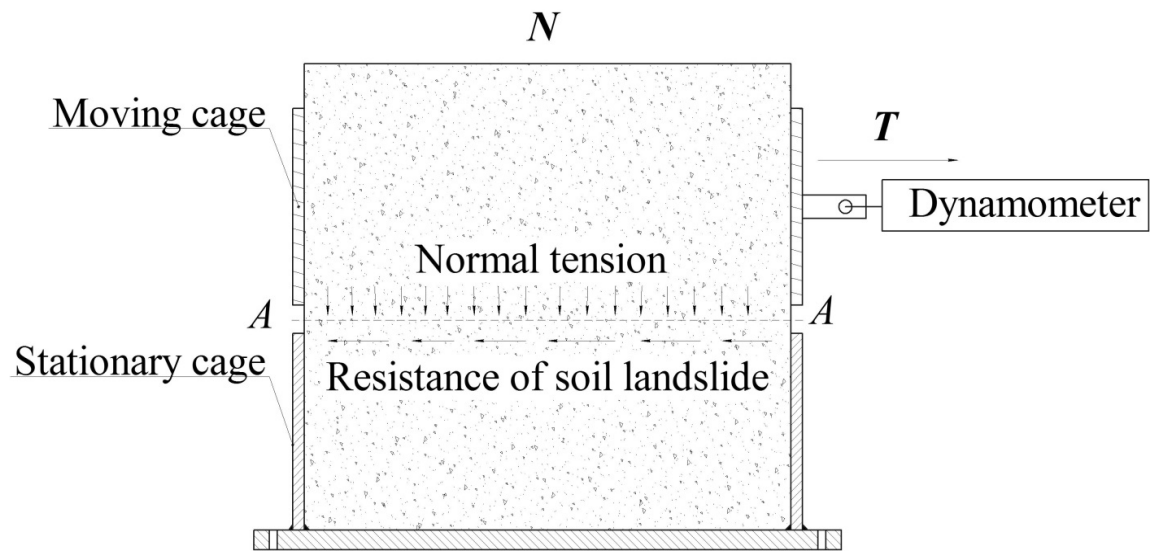

Fig. 1 - Scheme of adaptation to determine the resistance of soil landslide:

$T$-horizontal displacement force, $\mathbf{N}$;

$N$ - vertical force or normal load (depends on the weight of the soil and additional loads), $N$

For the measurements on the test field, a sample of soil (length $150 \mathrm{~mm}$, width 150 , and height depending on the location of determination of the resistance of the soil shift of the table 1).

A sample of soil was placed in a device (Fig. 1) with a cross-sectional area $A=0.0225$ SQM and gradually applied the displacement force $T$. In this case, the landslide stress $\tau$ appeared in the plane $A-A$.

After reaching $\tau_{\text {edge }}$ there is a shift in the ground in the plane $A-A$. By the results of research we established:

$$
\tau_{\text {edge }}=T / A \text {, }
$$

where $T$ is the horizontal sliding force, at which the movement of the upper layer began with respect to the lower one;

$\tau_{\text {edge }}$ is the resistance of soil landslide.

Height of researched samples

Table 1

\begin{tabular}{|c|c|c|}
\hline № & $\begin{array}{c}\text { Depth of determination of the } \\
\text { resistanceof soil landslide, } \mathrm{mm}\end{array}$ & $\begin{array}{c}\text { Sample height, } \\
\mathrm{mm}\end{array}$ \\
\hline 1 & 100 & 200 \\
\hline 2 & 200 & 300 \\
\hline 3 & 300 & 400 \\
\hline 4 & 400 & 500 \\
\hline
\end{tabular}

Normal stresses were determined according to the correlation:

$$
\sigma=\frac{N}{A} .
$$

The coefficient of internal friction $f$ and specific gravity $c$ were determined graphically (Figure 2). 


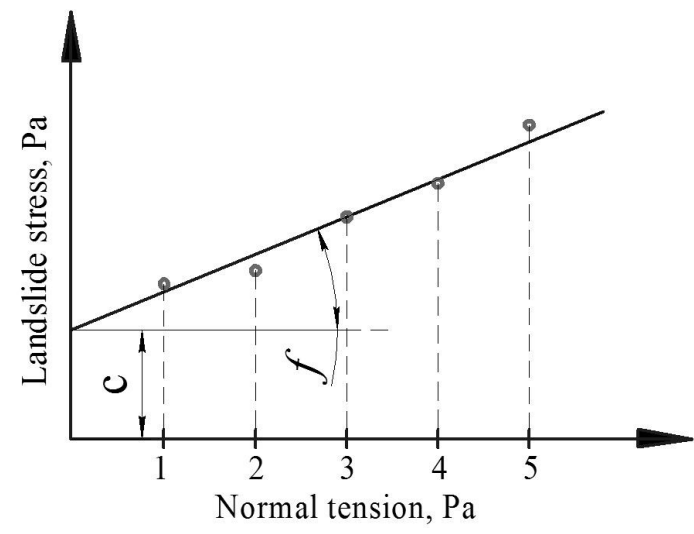

Fig. 2 - Schedule for determining the coefficient of internal friction $f$ and specific coupling $c$

In order to take into account the influence of the root system of agricultural crops on the degree of fastening of abrasive particles in the ground, the research was carried out in the fields after harvesting. In this case, the difference between the resistance of the soil shift, containing the root system and without it at the same depth (Table 2) was determined.

To determine the effect of soil moisture on the value of the coefficient of internal friction $f$ and specific traction on different soil types, studies have been carried out in accordance with the table 2 .

\section{Characteristics of Fields}

Table 2

\begin{tabular}{|c|c|c|c|c|c|}
\hline № & Location & Coordinates & $\begin{array}{c}\text { Type of soil } \\
\text { (mechanical structure) }\end{array}$ & Plants & $\begin{array}{c}\text { Soil } \\
\text { humidity, \% } \\
\end{array}$ \\
\hline 1 & Ovruch district & $\begin{array}{c}\text { latitude: } 51,27799804, \\
\text { longitude: } \\
28,80246162 . \\
\end{array}$ & loamy & After corn & 10,06 \\
\hline 2 & Ovruch district & $\begin{array}{c}\text { latitude: } 51,27799804 \text {, } \\
\text { longitude: } \\
28,80246162 .\end{array}$ & loamy & After corn & 8,21 \\
\hline 3 & $\begin{array}{l}\text { Zhytomyr } \\
\text { district }\end{array}$ & $\begin{array}{c}\text { latitude: } 50,13356399 \\
\text { longitude: } \\
28.78126144\end{array}$ & Clayey soil & $\begin{array}{l}\text { After winter } \\
\text { wheat }\end{array}$ & 16,8 \\
\hline 4 & $\begin{array}{l}\text { Zhytomyr } \\
\text { district }\end{array}$ & $\begin{array}{c}\text { latitude: } 50,13356399 \\
\text { longitude: } \\
28,78126144\end{array}$ & Clayey soil & $\begin{array}{l}\text { After winter } \\
\text { wheat }\end{array}$ & 14,3 \\
\hline 5 & Korosten district & $\begin{array}{c}\text { latitude: } \\
\text { 50,78765206 } \\
\text { longitude: } \\
28,34549904 \\
\end{array}$ & Sandy & $\begin{array}{l}\text { Perennial mead- } \\
\text { ow grasses }\end{array}$ & 8,6 \\
\hline 6 & $\begin{array}{l}\text { Korosten } \\
\text { district }\end{array}$ & $\begin{array}{l}\text { latitude: } \\
\text { 50,78765206 } \\
\text { longitude: } \\
28,34549904 \\
\end{array}$ & Sandy & $\begin{array}{l}\text { Perennial mead- } \\
\text { ow grasses }\end{array}$ & 7,3 \\
\hline 7 & $\begin{array}{l}\text { Vinnytsia } \\
\text { region, Koziatyn } \\
\text { district }\end{array}$ & $\begin{array}{c}\text { latitude: } \\
\text { 49,79478502 } \\
\text { longitude: } \\
28,73422623\end{array}$ & Clayey soil & After soya & 13,3 \\
\hline 8 & $\begin{array}{l}\text { Vinnytsia } \\
\text { region, Koziatyn } \\
\text { district }\end{array}$ & $\begin{array}{c}\text { latitude: } \\
\text { 49,79478502 } \\
\text { longitude: } \\
28,73422623\end{array}$ & Clayey soil & After soya & 17,7 \\
\hline
\end{tabular}




\section{Results of research}

The installation for studying the degree of fastening of the abrasive particles in the soil and the coefficient of internal friction of the soil is presented in Fig. 3. All studies were carried out in the spring-autumn period of 2018.

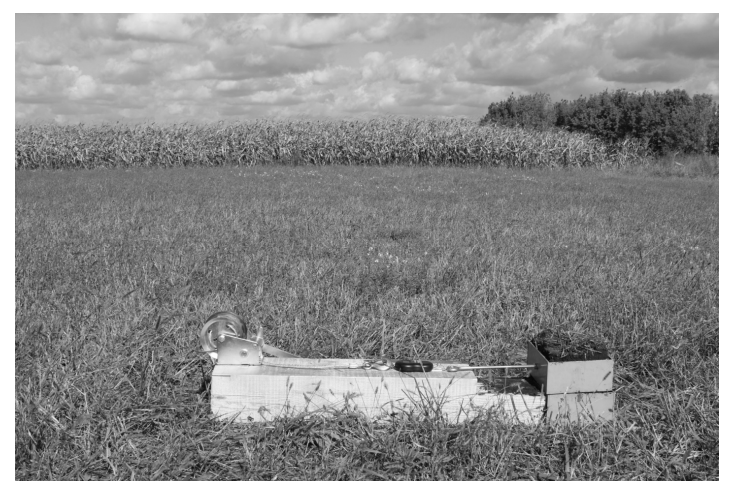

Fig. 3 - Installation for studying the degree of fastening

of the abrasive particle in the soil and the coefficient of internal friction of the soil

Measurement of soil moisture was carried out by drying to a constant mass in accordance with National Standard of Ukraine B.V.2.1-17:2009 [7].

Results of experiment number 1 (table 2) are presented in Fig. 4 - 6.

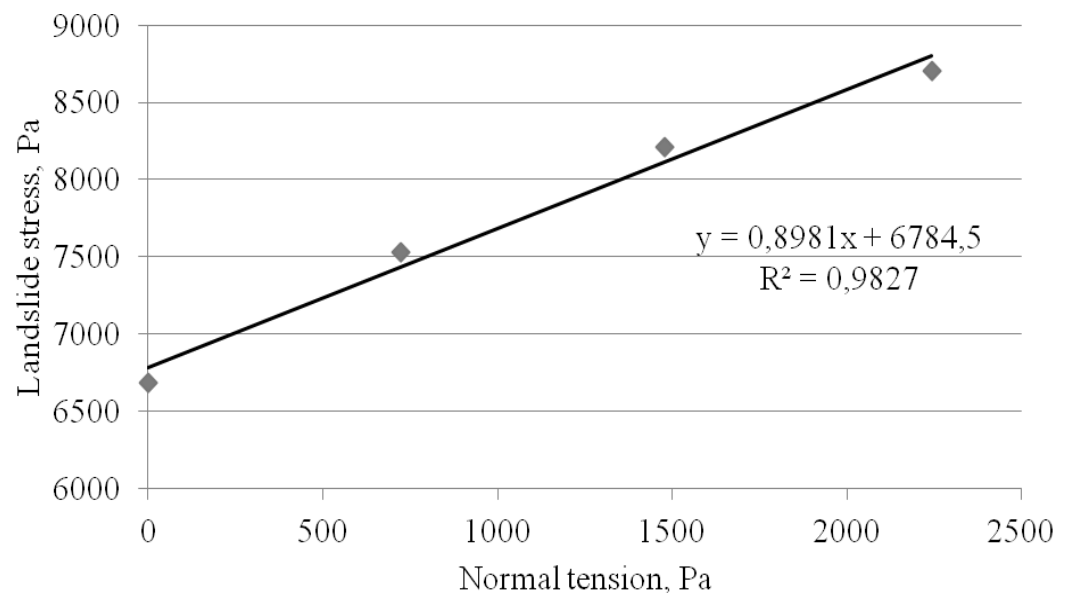

Fig. 4 - Results of researches on determining the coefficient of internal friction $f$ and specific gravity on the sandy soils (cut depth $100 \mathrm{~mm}$.)

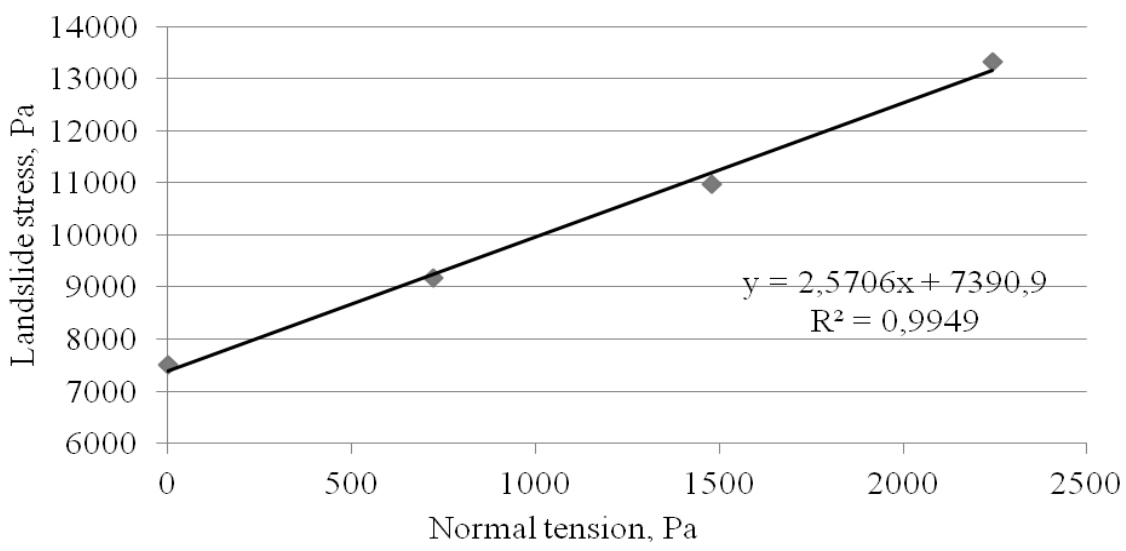

Fig. 5 - Results of studies on determining the coefficient of internal friction $f$ and specific adhesion $c$ on the sandy soils (cut depth of $200 \mathrm{~mm}$ )

Based on the graph, one can conclude that the coefficient of internal friction of sandy soils at humidity 10,06 is 0,8981 , and the specific gravity is $6784,5 \mathrm{~Pa}$. 
Research of the degree of fixation of abrasive particle in the soil

At a depth of $300 \mathrm{~mm}$, experiments on sandy soils were not carried out because the goose layer was $260 \mathrm{~mm}$. To determine the pouring of the root system of plants by the coefficient of internal friction $f$ and specific adhesion $c$ from the conducted experiments with the presence of the root system.

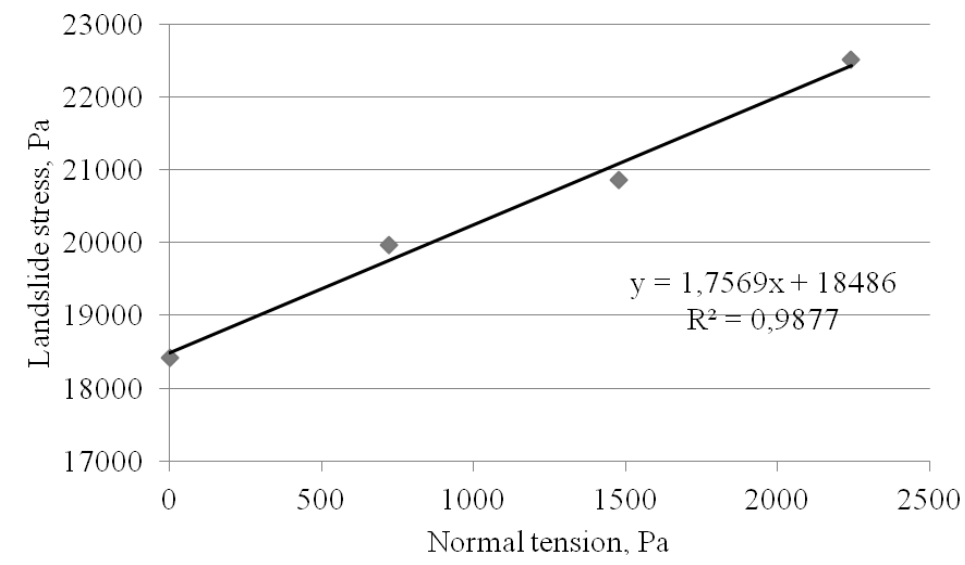

Fig. 6 - Results of researches on determining the coefficient of internal friction $f$ and specific gravity on the sandy soils (cut depth $100 \mathrm{~mm}$ )

The results of other researches carried out are given in table 3 .

\section{Results of research}

\begin{tabular}{|c|c|c|c|c|c|c|c|}
\hline № & Location & 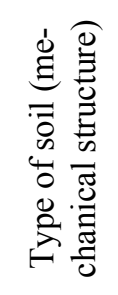 & 莺 & Available root system & 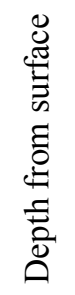 & 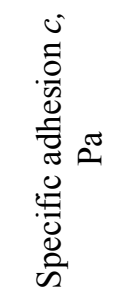 & 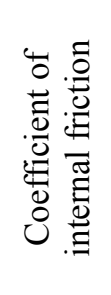 \\
\hline \multirow{3}{*}{1} & \multirow{3}{*}{ Ovruch district } & \multirow{3}{*}{ Sandy } & \multirow{3}{*}{10,06} & \multirow{2}{*}{ No root system } & 100 & 6784,5 & 0,8981 \\
\hline & & & & & 200 & 7390,9 & 2,5706 \\
\hline & & & & With corn root system & 100 & 18486 & 1,7569 \\
\hline \multirow{2}{*}{2} & \multirow{2}{*}{ Ovruch district } & \multirow{2}{*}{ Sandy } & \multirow{2}{*}{$8,21 \%$} & \multirow{2}{*}{ No root system } & 100 & 6239,03 & 0,8034 \\
\hline & & & & & 200 & 8125,76 & 2,3681 \\
\hline \multirow{2}{*}{3} & \multirow{2}{*}{ Korosten district } & \multirow{2}{*}{ Loamy } & \multirow{2}{*}{8,6} & \multirow{2}{*}{ Root system of perennial grass } & 100 & 5397,3 & 1,4215 \\
\hline & & & & & 200 & 5689,6 & 1,5686 \\
\hline \multirow{2}{*}{4} & \multirow{2}{*}{ Korosten district } & \multirow{2}{*}{ Loamy } & \multirow{2}{*}{7,3} & \multirow{2}{*}{ Root system of perennial grass } & 100 & 5134,68 & 1,3872 \\
\hline & & & & & 200 & 5702,4 & 1,4973 \\
\hline \multirow{2}{*}{5} & \multirow{2}{*}{ Koziatyn district } & \multirow{2}{*}{ Clayey } & \multirow{2}{*}{13,3} & \multirow{2}{*}{ Soya root system } & 100 & 5615,34 & 1,4022 \\
\hline & & & & & 200 & 11435 & 2,1591 \\
\hline \multirow{2}{*}{6} & \multirow{2}{*}{ Koziatyn district } & \multirow{2}{*}{ Clayey } & \multirow{2}{*}{17,7} & \multirow{2}{*}{ Soya root system } & 100 & 6663,1 & 1,4322 \\
\hline & & & & & 200 & 11936,2 & 2,2945 \\
\hline \multirow{2}{*}{7} & \multirow{2}{*}{ Zhytomyr district } & \multirow{2}{*}{ Clayey } & \multirow{2}{*}{14,3} & \multirow{2}{*}{ Root system of winter wheat } & 100 & 5834,15 & 1,3921 \\
\hline & & & & & 200 & 9721,89 & 2,1342 \\
\hline \multirow{3}{*}{8} & & & & 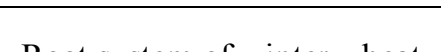 & 100 & 6407,1 & 1,4596 \\
\hline & Zhytomyr district & Clayey & 16,8 & Root system of winter wheat & 200 & 10927,8 & 2,429 \\
\hline & & & & No root system & 100 & 5640,45 & 1,0463 \\
\hline
\end{tabular}


The presence of the root system significantly increases the coefficient of internal friction and the degree of attachment of abrasive particles (specific gravity $c$ ) on sandy soils, the presence of the root system of maize at a depth of $100 \mathrm{~mm}$ increases the data in 1.95 and 2.72 times respectively, and on clay soils, the presence of root wheat systems increases respectively 1.39 and 1.14 times, respectively. Such a significant difference in the indicators is due to the difference in the root system of wheat and corn.

Increasing the humidity on clay soils increases the coefficient of internal friction and the degree of fastening of abrasive particles (specific gravity $c$ ). This process will continue until the soil is saturated with moisture and the appearance of free water, after which the coefficient of internal friction and specific adhesion will begin to decrease. The reduction of the coefficient of internal friction and specific gravity on sandy and sandy soils is also observed when the soil is saturated with moisture and the appearance of free water, but the moisture content in which it appears in this case is much smaller. With the increase in the depth of the research from the surface of the soil, the degree of fastening of abrasive particles (specific gravity $c$ ) increases. Thus, with the change in depth from $100 \mathrm{~mm}$ to $200 \mathrm{~mm}$ on clay soils, specific gravity increases in $1.66 \ldots 2.0$ times, on sandy and sandy - in $1.05 \ldots 1.3$ times.

\section{Conclusions and directions for further researches}

1. The degree of fixture of abrasive particles on clay soils is greater than on loamy and sandy soils.

2. Increased soil moisture leads to an increase in the degree of fixture of abrasive particles on all types of soils, this pattern is observed until the soil is saturated with moisture.

3. The presence of the root system significantly increases the degree of fastening of abrasive particles in the soil and depends on the type of root system and its state.

In the future it is necessary to investigate the effect of the degree of fixture of abrasive particles of soil on the intensity of wear of working bodies of soil-working machines.

\section{References}

1. Tenenbaum M.M. Soprotivlenie abrazivnomu iznashivaniju / M.M. Tenenbaum. - M.: Mashinostroenie, 1976. - $271 \mathrm{~s}$.

2. Mehaniko-tehnologichni vlastivosti sil's'kogospodars'kih materialiv: Pidruchnik / O. M. Carenko, D. G. Vojtjuk, V. M. Shvajko ta in.; Za red. S. S. Jacuna. - K.: Meta, 2003. - 448 s.

3. Bartenev I.M. Iznashivajushhaja sposobnost' pochv i ee vlijanie na dolgovechnost' rabochih organov pochvoobrabatyvajushhih mashin / I.M. Bartenev, E.V. Pozdnjakov // Lesotehnicheskij zhurnal 2013. - №3 114-123.

4. Liskin I.V. Obosnovanie parametrov iskusstvennoj pochvennoj sredy dlja laboratornogo issledovanija iznashivanija lezvija / I.V. Liskin, D.A. Mironov, R.K. Kurnbanov // Sel's'kohozjajstvennye mashiny i tehnologii. Moskva 2017. №4 - S. 37-42.

5. Godwin R.I., Spoor G. Soil Failure with Narrow Tines. Journal of Agricultural Engineering Research. 1977. Vol. 7; 22: 213-218.

6. Vadjunina A.F. Metody issledovanija fizicheskih svojst pochvy. / A.F. Vadjunina, Z.A. Korchagina // - M.: Agropromizdat, 1986. - 416 s.

7. DSTU B V.2.1-17:2009. Osnovi ta pidvalini budinkiv i sporud. Irunti. Metodi laboratornogo viznachennja fizichnih vlastivostej. Kiïv: Minregionbud Ukraïni. 2010. - 32 s.

\section{Дворук В.І., Борак К.В. Дослідження ступеню фіксації абразивного частинки у грунті.}

Розроблено адаптацію для вимірювання стійкості до зсуву грунту. Вивчено вплив типу і вологості грунту на вміст кореневої системи, на ступінь фіксації абразивних частинок у грунті. Встановлено закономірності ступеня фіксації абразивних частинок у грунті залежно від згаданих факторів. Визначено напрями подальших досліджень.

Ключові слова: абразивна частка, грунт, ступінь закріалення абразивних частинок, грунтообробні машини, сівалки, коефіцієнт внутрішнього тертя, питома вага. 